\title{
USING FUN ACTIVITIES TO IMPROVE LISTENING SKILL
}

\author{
Hanna Andyani \\ MTsN Mojokerto \\ hannaandyani@gmail.com
}

\begin{abstract}
Based on the researcher's experience in teaching English at MTsN Mojokerto, there are three problems dealing with the teaching of listening especially for the third year students: 1) most of the students' scores on listening test are still under the minimum passing criterion (KKM), which is 60; 2 most students are not very enthusiastic in listening activities; 3 ) it is difficult for students to understand native speech in a tape recorder. Based on the problems, the main purpose of the study is to improve the ninth grade students' listening skill using Fun Activity in the form of Games at MTsN Mojokerto. The design of this study was Classroom Action Research. The instruments were the listening tests, observation checklist and questionnaires. With the implementation of the games, the criteria of success were successfully achieved in Cycle 2. $74 \%$ of the total number of the students could get the scores more than 60 and $90 \%$ have positive responses on the implementation of games.
\end{abstract}

Key terms: Tic Tac Toe Game, Running Dictation Game, Whispering Game, Listening Skill.

The government of Indonesia has decided that English is one of the compulsory subjects especially for Junior High School and Senior High School students. The objective of teaching listening is that the students are able to understand the meaning in transactional and interpersonal discourses which tend to emphasize the interpersonal meaning variation, and to understand oral monologues. Students with good listening comprehension skills are better able to participate effectively in class (Brown, 2001:247). Listening is a medium for learners to get information and to understand the language. But listening has hardly got the attention of educators in teaching and learning of English as second or foreign language. Another reason why listening has been ignored is because there are still people who view listening as a passive skill.

Based on the researcher's experience in teaching English at MTsN Mojokerto, there are three problems dealing with the teaching of listening especially for the third year students: 1) most of the students' scores on listening test are still under the minimum passing criterion (KKM), which is $60 ; 2$ ) most students are not very enthusiastic in listening activities; 3 ) it is difficult for students to understand native speech in a tape recorder. In addition to the researcher's experience, the result of the preliminary study which was conducted by the researcher on 6th and 8th of May 2010 also revealed the same problems. From the questionnaires given to the students, it showed that from 36 students, $73 \%$ of the students have difficulties to understand native speech from the tape recorder, $51 \%$ have difficulties to keep up the information from the teacher, $73 \%$ have difficulties to complete the listening task, $57 \%$ have difficulties to keep up the information from the text they listened, and $89 \%$ of them stated that listening activities in 
their class was boring activities.

Those problems can be caused by two factors; 1 ) the teachers lack creativity to use available listening material; 2) the teachers seem to lack varieties in teaching listening. Therefore, in designing lessons and teaching materials to develop listening skills, students need to be motivated and stay motivated. If students are to continue to be motivated, they clearly need to be interested both in the subject they are studying and in the activities and topics presented (Harmer, 2001:53). The teacher should determine the suitability of the listening materials and the techniques used in classroom teaching. Brown (2001:81) offers "ten commandments" for motivating learners in the classroom activities. All of the ten items focus on what the teacher can do to stimulate intrinsic motivation. The two of the commandments are considered appropriate to motivate students in listening activity. Those two commands are "creating a pleasant, relaxed atmosphere in the classroom" and "making the languages classes interesting".

One technique that is considered useful to create relaxed and pleasant atmosphere in the classroom and interesting for the learners is by the use one of Fun Activity which is Games. Games which are defined as activities with rules, competition and the element of fun (Deesri, 2002), can be a tool to raise the students' motivation. Games can motivate students because they are amusing, interesting, and sometimes challenging. Games can be used to give practice in all language skills: listening, speaking, reading, and writing. Uberman (1998) states that games offer students a fun-filled and relaxing learning atmosphere. Games give a chance for students to use language in a non-stressful way.

Games may help learners develop their ability to work in group, to cooperate and to compete. Some recent research studies, for example Wright (1983), Huyen and Nga (2003) and Yagang (2008) give insight that games can be used to support teaching and learning activities. Games are beneficial for motivating students and increasing their vocabulary mastery. Through the application of language games in the learning process, the students will experience the language they are learning. Inserting games in the teaching and learning activity will make the learning process joyful and interesting. Thus, the better achievement in the language learning can be achieved.

Many experienced textbook and methodology manuals writers have argued that games are not just time-filling activities but have a great educational value. W. R. Lee holds that most language games make learners use the language instead of thinking about learning the correct forms. He also says that games should be treated as central not peripheral to the foreign language teaching programmed. A similar opinion is expressed by RichardAmato, who believes games to be fun but warns against overlooking their pedagogical value, particularly in foreign language teaching (Uberman, 1998:20).

Games are often used as short warm-up activities or when there is some time left at the end of a lesson (Cox, 1999). Yet, as Lee observes, a game "should not be regarded as a marginal activity filling in odd moments when the teacher and class have nothing better to do". Games ought to be at the heart of teaching foreign languages. Rixon suggests that games be used at all stages of the lesson, provided that they are suitable and carefully chosen (Uberman, 1998:20).

The use of games in ESL Curriculum requires careful planning, design and execution. Games should not be used as ice breakers or time fillers only. They should be used as part of the instructional design. Games should be seen and used as a motivational tool (Mckenzie, 2011).

This research uses Fun Activity in the form of Games which consists of Tic-Tac-Toe Game, Running Dictation Game, and Whispering Game in listening class. There are several 
reasons why Tic-Tac-Toe activities work well in the classroom. Tic-Tac-Toe Game is very simple. The simplicity of Tic-Tac-Toe makes it ideal as a pedagogical tool for teaching the concepts of combinatorial game theory and the branch of artificial intelligence that deals with the searching of game trees. Because this game using teacher's voice, hopefully it can solve the student's problem with native speech. As Brown (2001: 254) suggested that learners need to be able to comprehend delivered at varying rates of speed and delivered with few pauses. Teacher can provide a practice by producing teacher-talk at the right level for students.

There are several reasons why running dictation game activities work well in the classroom. Dictation has great benefits as an activity type, including the fact that students are active during and after the dictation, that it is good for mixed-ability (because it is entirely receptive, requiring no output from the student) and large classes, and provides access to interesting texts. Another benefit is that it is a multi skilled activity, potentially involving listening, writing, reading and speaking. It is a great way to focus the attention of overanimates students or daydreamers at the back of the class. Furthermore, dictation is a very flexible activity with numerous variations (Wilson, 2008:90). Because of these advantages, hopefully Running Dictation Game can solve the problem of the students' statement that listening activities in their class was boring activities.

There are several reasons also why Whispering Game activities work well in the classroom. Whispering Game can be done with any. Whispering Game also has some main reasons to be played, as an ice-breaker at events and as a fun game to see how language can evolve. Whispering Game aims to assist students with memorizing vocabulary and the spelling of words, and also to give them a chance to use the vocabulary correctly (Hakim, 2009:53). Because of these advantages, hopefully Whispering Game can solve the students' difficulties to keep up the information from the text that they listen and to complete the listening task.

The researcher considers that Fun Activity in the form of Games will be an alternative strategy in improving students' listening skill. That is why the researcher would like to use Game as her technique in teaching listening to help the students to solve their problems. Based on the problems, the main purpose of the study is to improve the ninth grade students' listening skill using Fun Activity in the form of Games at MTsN Mojokerto.

\section{METHOD}

The research design of this study was classroom action research which focuses on a particular group of students in a certain classroom. The classroom action research employed in this study followed Kemmis and Mc Taggart's model. Each cycle consists of four stages: (1) planning, (2) implementing, (3) observing, and (4) reflecting. The research was conducted at MTsN Mojokerto, located at J1. Raya Sambiroto 112, Sooko, Mojokerto. This research started with the preliminary study to identify, analyze, and state the problems faced by the teacher and the students. The preliminary study was conducted on 6th and 8th of May, 2010 to the students in the class VIII-B of MTsN Mojokerto. The class consisted of 36 students. In carrying out the preliminary study, the researcher used an interview guide and questionnaire. The researcher interviewed the students to know the teaching and learning process in the classroom especially in listening. The researcher also gave questionnaire related to students' problems in listening.

In this step researcher and the collaborator prepared the strategy of teaching listening using Game. Game consists of Tic-Tac-Toe Game, Running Dictation Game, and Whispering Game. The steps of implementing Game were taken from Kang Guru Indonesia. 
(2009). Listen \& Learn with Kang Guru Indonesia. Teacher Guide (SMP Package) (pp.2032).

The lesson plan was designed by the researcher together with the collaborator. The lesson plan was implemented in 80 minutes. The materials in the lesson plan were developed based on the content standard 2006. The teaching learning procedures were divided into three stages. They were pre-listening, whilst-listening, and post-listening

To determine whether the cycle is successful or not, the following criteria are set up. The improvement of students' score on the listening test. If at least $55 \%$ or more of students' can reach 60 or more on the listening test, it is considered successful. It is based on the students' listening scores on listening which are still under the minimum passing criterion of 60 .

\section{FINDINGS}

Based on the students' learning process and the result of the test, it was found out that both were improved. It means that Game can improve the students' participation in teaching and learning process and students' achievement in listening. Most of the students gradually improved their participation in the listening activities which consist of three phases: pre listening activities, whilst listening activities and post listening activities. Student' participation generally improved from one meeting to the next meeting.

\section{Figure 4.1 The Result of Assessing the Stu- dents' Performance}

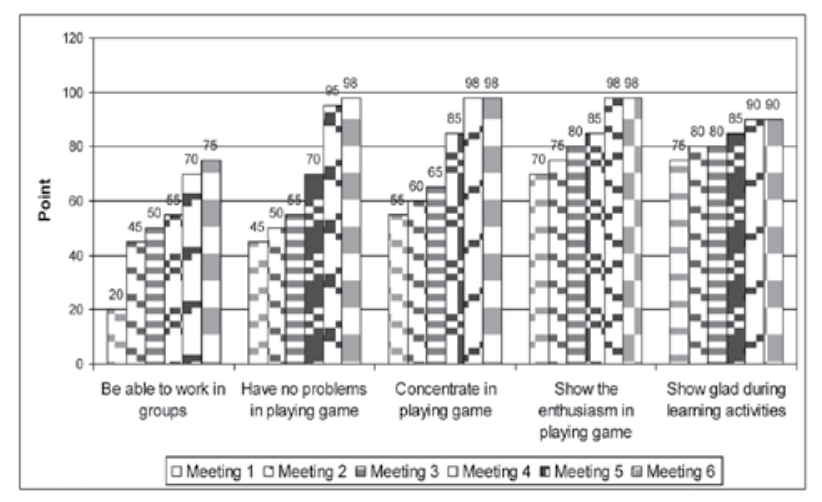

To be more specific, it was found out that in listening score only $12(31 \%)$ students got more than 60 . The students achievement was improved in first cycle when 20 (51\%) got more than 60 . However, the result of students' achievement in the first cycle has not achieved the criteria of success yet, that the researcher should continue to the next cycle. In the second cycle, it was found that 29 (74\%) students got more than 60 . It means that the criteria of success have been achieved. The information about the improvement of students listening score can be seen in Figure 4.2

Figure 4.2 The Result of Assessing Students' Achievement in Listening

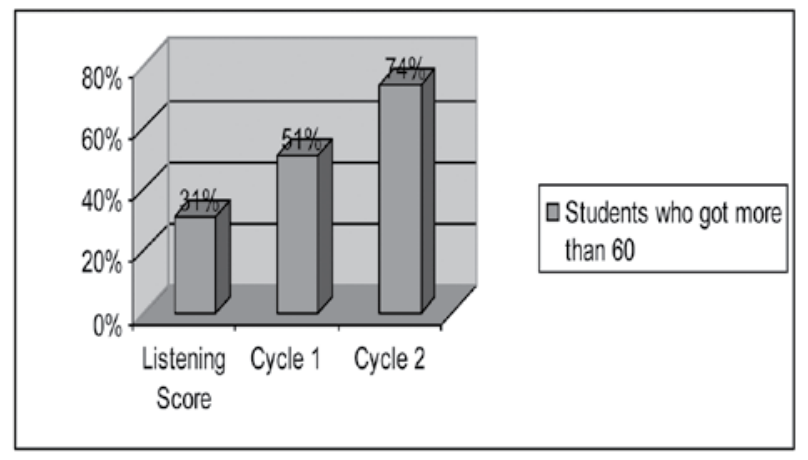

To know the students' responses to the implementation of Game in the listening activities, every student was given a questionnaire. The finding showed that most of the students have good responses on the implementation of Game. From the result of observation and students questionnaires it can be seen that 95\% students like learning strategy by Game, 97\% students consider that listening using Game is interesting, 87\% students think Game can make the class interesting and fun, 95\% students consider that Game can make teaching and learning activities is not boring, $87 \%$ students think that storytelling motivates them in listening, 90\% students think that they are not feel under pressure to accomplish the listening task by Game, $80 \%$ students think that by storytelling, their listening skill improve. In conclusion, $90 \%$ of the students have good response toward the 
listening activities and $10 \%$ of the students have fairly good response.

\section{DISCUSSION}

Training students to listen is one of the hardest things foreign language teachers do. The implementation of Game as the strategy in listening class gave valuable contributions to the English language learning. The use of this strategy which gave learner-centered process in listening class would make the students conscious of the processes underlying the learning. They were involved in learning more effectively and interesting way.

Vandergrift (1999:174) states that the use of listening strategies can make authentic texts more accessible in the early stages of learning a language, so that the process becomes more relevant and interesting to the learners. This statement is in line with the result of the listening comprehension using Game.

In relation to implementation of Game, the strengths of Game were elaborated. Game could help and encourage the students to sustain their interest and work. The students did the task in groups. They could be more responsible in doing tasks. The implementation of Game can make the students more actively involved in the teaching and learning process. From the result of the questionnaires, it can be seen that most of students have good responses to the teaching of listening using Game.

During the process of game the students were active and the game also motivated the students to ready harder. The implementation this game gave the student challenges to improve their listening skill when they dictated the sentences of the text to their group mates. It was proved by the result of the researcher in which the game was effective in listening class and the students listening achievements were improved.

To know whether the teaching and learning process has achieved the objective or not, it is necessary to conduct evaluation. There are two kinds of evaluation used in this research. The first evaluation is dealing with the process of implementation of the Game. It was done by observing the teaching and learning process. The second evaluation is dealing with the result of the implementation of the Game. It was done by assessing the listening test. The result was used to identify the students' achievement in listening using Game.

The implementation of listening strategy in teaching listening made the students' interested in listening subject and motivated the students to study listening. As a result, the students' listening achievement improved.

From the result of listening score and test, it indicated that the students' achievements gradually increased. The score obtained by the students in each test, indicating their listening comprehension gradually improved. There was a positive impact of applying the game. In short, the game gradually increased the students' listening comprehension achievement.

\section{CONCLUSION}

Based on the research findings, it was concluded that the implementation of Games in teaching listening comprehension could improve the students listening ability. This improvement could be proved by the students listening achievement and the score obtained by the students, i.e. the numbers of students who obtained the minimum passing score have been $74 \%$ and based on the result of questionnaires, more than $75 \%$ students have positive response on the implementation of the Games.

The steps of the three games are as follows: Tic Tac Toe Game: (1) showing the picture and giving some questions related to the picture, (2) writing some words related to the topic on the whiteboard and reading the words then asking the students to repeat, (3) telling to the students how to play Tic-Tac-Toe Game and also the rule of the Game, (4) dividing the 
class into two teams, A and B and draw grid on the board which consists of 9 squares, (5) each student in each team chooses a number from the grids, group A should answer, if he/ she has right answer, the teacher will write $\mathrm{A}$ in a square but if he/she has wrong answer and group B can answer it correctly, the teacher will write B in a square, while both of the students come forward, the rest of the students also listen to the teacher and write the ingredients of the procedure texts.

Running Dictation Game: (6) showing the picture and giving some questions related to the picture, (7) writing some words related to the topic on the whiteboard and reading the words then asking the students to repeat, (8) telling to the students how to play Running Dictation Game and also the rule of the game, (9) finding some short sentences and write each sentence in a paper then pin each paper on the tree, (10) dividing the students into some groups and all of the students in a group make a line. (11) student 1 in each group run to the tree 1 , read the sentence, remembers it, run back to their group, and quietly dictates what he/she remembered to student 2, student 2 listens carefully and then writes it on a paper, after that student 1 takes his/her position behind student 5, (12) after writing on a

\section{REFERENCES}

Brown, H.D. (2001). Teaching by Principle: An Interactive Approach to Language Pedagogy. New York: Addison Wesley Longman.

Cohen, A.D. (1994). Assessing Language Ability in the Classroom. Boston: Heinle \& Heinle.

Cox, C. (1999). Teaching Language Art. Boston: Allyn and Bacon

Deesri, A. (2002). Games in the ESL and EFL Class. The Internet TESL Journal 8 (9), (Online), (http://iteslj.org/techniques/Deesri Games.html, Accessed on February 27th, 2008). paper, student 2 gives the paper to students 3 , then student 2 run to the tree 2 and so on, play this Game until all the group has written down all the sentences.

Whispering Game: (13) showing the picture and giving some questions related to the picture, (14) writing some words related to the topic on the whiteboard, reading the words and asking the students to repeat, (15) telling to the students how to play Whispering Game and also the rule of the game, (16) finding some short sentences and write each sentence in a paper then copies it based on the number of the group, (17) dividing the students into some groups, each group must choose one person to write down a text, to be a writer and one person to be a runner, then all of students in each group make a line, (18) student 1 in each group read the sentence 1 , remembers it, put down the paper, run back to their group, and quietly whisper what he/ she remembered to student 2 then student 2 listens carefully, remember it, whisper what he/she remember to student 3 and soon, the last students in each group remember the sentence and write it on the paper, play this game until all the group has written down all the sentences.

Hakim, A.K. (2009). Games in Language Class. In K. Yusuf (Ed). Serba-Serbi Pengajaran Bahasa (pp. 46-56). Surabaya: EF Press.

Harmer, J. (2001). The practice of English language Teaching. Malaysia: Longman.

Huyen, N.T.T. \& Nga, K.T.T. (2003). The Effectiveness of Learning Vocabulary through Games. Asian EFL Journals, (Online), (http://www asian-efljournal.com/dec 03 sub.Vn.html, Accessed on February 27th 2008).

Kang Guru Indonesia. (2009). Listen and Learn with Kang Guru Indonesia: Teacher 
Guide (SMP Package).

Kemmis, S., \& Mc Taggart, R. (Eds). (1988). The Action Research Planner. Cilong: Deakin University Press.

McKenzie, R. (2004). Using Games to Teach ESL-English Lesson, (Online), (http:/ / www.eslteachersboard.com/cgibin/lesson/index.pl?read=1343, Accessed on June 9th, 2011).

Uberman, A. (1998). The Use of Games for Vocabulary Presentation and Revision. English Teaching Forum 36(1):20, (Online), (http://exchanges.state. gov/forum/vols/vol36/no1/p20. html, Accessed on March 5th , 2009).

Vandergrift, L., (1999). Facilitating Second Language Listening Comprehension: Acquiring Successful Strategies. ELT
Journal, Vol. 53, 3 July 1999, Oxford University Press.

Wikipedia. (2010). Tic-Tac-Toe, (Online), (http://www.skripsi-tesis.com/ site/http:/ / en.wikipedia.org/wiki/ Tic-tac-toe, Accessed on June 6th , 2010).

Wilson, J.J. (2008). How to Teach Listening. England. Pearson Education.

Wright, A., (1983). Games in Language Learning, Cambridge. Cambridge University Press.

Yagang, F, (2008). Listening Problems and Solutions, English Teaching Forum, (online), (http:English Teaching Forum Online- Bureau of Educational and Cultural Affairs.htm., Accessed on December 31st, 2008) 
